\title{
Nasal Mucociliary Clearance in Subjects With COPD After Smoking Cessation
}

\author{
Juliana T Ito MSc, Dionei Ramos PhD, Fabiano F Lima, Fernanda MM Rodrigues MSc, \\ Paulo R Gomes MD, Graciane L Moreira MSc, Mariangela Macchione PhD, \\ Alessandra C Toledo PhD, and Ercy MC Ramos PhD
}

\begin{abstract}
BACKGROUND: Exposure to cigarette smoke causes significant impairment in mucociliary clearance (MCC), which predisposes patients to secretion retention and recurrent airway infections that play a role in exacerbations of COPD. To determine whether smoking cessation may influence MCC and frequency of exacerbations, the following groups were evaluated: ex-smokers with COPD, smokers with COPD, current smokers with normal lung function, and nonsmokers with normal lung function. METHODS: Ninety-three subjects were divided into 4 groups: ex-smokers with $\operatorname{COPD}(n=23,62.4 \pm 8.0 \mathrm{y}, 13$ males $)$, smokers with COPD $(n=17,58.2 \pm 8.0 \mathrm{y}, 6$ males $)$, current smokers ( $n=27,61.5 \pm 6.4 \mathrm{y}, 17$ males), and nonsmokers ( $n=26,60.8 \pm 11.3 \mathrm{y}, 7$ males). MCC was evaluated using the saccharin transit time (STT) test, and the frequency of exacerbations in the last year was assessed by questionnaire. The Kruskal-Wallis test followed by Dunn's test were used to compare STT among groups, and the Goodman test was used to compare the frequency of exacerbations. RESULTS: STT of smokers with COPD (16.5 [11-28] min; median [interquartile range $25-75 \%])$ and current smokers $(15.9$ [10-27] $\mathrm{min})$ was longer compared with ex-smokers with COPD $(9.7[6-12] \mathrm{min})$ and nonsmokers $(8[6-16] \mathrm{min})(P<.001)$. There was no difference in STT values between smokers with COPD and current smokers, and these values in ex-smokers with COPD were similar to the control group $(P>.05)$. The frequency of exacerbations was lower in ex-smokers with COPD compared with smokers with COPD. CONCLUSIONS: One year after smoking cessation, subjects with COPD had improved mucociliary clearance. Key words: chronic obstructive pulmonary disease; smoking; mucociliary clearance; disease exacerbation; smoking cessation; respiratory infections. [Respir Care 2015;60(3):399-405. (c) 2015 Daedalus Enterprises]
\end{abstract}

\section{Introduction}

Smoking cessation is the most effective intervention in stopping the progression of COPD, as well as increasing

\footnotetext{
Ms Ito, Dr Ramos, Mr Lima, Ms Rodrigues, and Dr Ramos are affiliated with the Department of Physiotherapy, Universidade Estadual Paulista (UNESP), Presidente Prudente; Dr Gomes is affiliated with the Clinic of Medical Specialties, a partner of UNESP, Clinical Center, Presidente Prudente; Ms Moreira is affiliated with the Department of Medicine in Pneumology, Federal University of São Paulo/Paulista School of Medicine, São Paulo; Drs Macchione and Toledo are affiliated with the Department of Pathology, University of São Paulo School of Medicine, São Paulo, São Paulo, Brazil.
}

This research was supported by the Fundação de Amparo à Pesquisa do Estado de São Paulo and the Programa Institucional da Pró-Reitoria de Extensão-Universidade Estadual Paulista. survival and reducing morbidity. ${ }^{1}$ Constant exposure to cigarette smoke and other noxious particles causes a chronic inflammatory response in the lungs, characterized by parenchymal tissue destruction and disruption of normal repair and defense mechanisms, leading to an increased risk of exacerbations. ${ }^{2,3}$

Inhaled cigarette smoke induces a significant decrease in mucociliary clearance (MCC), which is the main de-

\footnotetext{
The authors have disclosed no conflicts of interest.

Correspondence: Ercy Mara Cipulo Ramos PhD, Departamento de Fisioterapia, Universidade Estadual Paulista, Rua Roberto Simonsen 305, Presidente Prudente, São Paulo CEP 19060-900, Brasil. E-mail: ercy@fct.unesp.br.
}

DOI: $10.4187 /$ respcare. 03266 


\section{Mucociliary Clearance in COPD After Smoking Cessation}

fense mechanism of the upper and lower airways. Its efficiency relies on appropriate interactions between the epithelial structure, ciliary beat frequency, and the quantity and quality of mucus. ${ }^{4,5}$ The impairment of MCC leads to retention of secretions and recurrent airway infections that play a role in exacerbations of COPD. ${ }^{6-9}$ Exacerbations of COPD have a negative impact on mortality rates, ${ }^{10,11}$ on health-related quality of life, and on $\mathrm{FEV}_{1}$, in addition to representing a hugely expensive burden on healthcare resources. ${ }^{12}$

Studies have shown that the impairment of MCC in smokers was related to the intensity of the smoking habit ${ }^{13}$ and that smoking cessation improved nasal MCC by $15 \mathrm{~d}$ after quitting smoking and that the improvement persisted over 6 months. ${ }^{14}$

Some studies found modified mucociliary function in subjects with COPD, ${ }^{15,16}$ and ciliary beat frequency was markedly lower in these subjects. ${ }^{17}$ It is known that smoking cessation reduces the decline in $\mathrm{FEV}_{1}$, respiratory symptoms, and airway inflammation and that it improves longterm prognosis. ${ }^{18-20}$ However, it is still unknown whether smoking cessation may modify MCC in patients with COPD and whether this might contribute to fewer exacerbations. Therefore, the aim was to evaluate MCC in ex-smokers with COPD and to investigate the frequency of exacerbations in subjects with COPD.

\section{Methods}

\section{Study Design and Subjects}

This cross-sectional observational study was undertaken with 93 subjects, age $45-80$ y. Subjects were divided into 4 groups: ex-smokers with COPD, who had ceased smoking for at least $1 \mathrm{y}$; smokers with COPD; current smokers with normal lung function; and age-matched nonsmokers with normal lung function. The sample was composed of subjects and staff from the Studies and Assistance Center in Physiotherapy and Rehabilitation and participants of the Anti-tobacco Orientation and Awareness program, both at the UNESP Universidade Estadual Paulista, São Paulo, Brazil.

Inclusion criteria for current smokers and nonsmokers included a normal lung function confirmed by spirometry. Individuals with COPD established by the Global Initiative for Chronic Obstructive Lung Disease (GOLD) ${ }^{2}$ guidelines and clinically stable (no exacerbations or infections in the last $3 \mathrm{mo}$ ) were included. Individuals with cystic fibrosis, bronchiectasis, immotile ciliary syndrome, a history of nasal or trauma surgery, or inflammation process in the upper airway (determined during the initial assessment) were excluded from the study.

All participants were informed about the objectives and procedures of the study, and they signed the consent form,

\section{QUICK LOOK}

\section{Current knowledge}

Exposure to cigarette smoke causes impairment in mucociliary clearance, which predisposes patients to secretion retention and recurrent airway infections. These recurrent infections may play a role in exacerbations in patients with COPD.

\section{What this paper contributes to our knowledge}

Subjects with COPD who quit smoking for 1 y had improved nasal mucociliary clearance compared with those who continued to smoke. Ex-smokers with COPD also had lower exhaled carbon monoxide and tended to have fewer exacerbations, although this difference was not statistically significant.

according to the Declaration of Helsinki of the World Medical Association. The study was approved by the institution's ethics and research committee (study 122/2010).

\section{Protocol}

All subjects' personal data, lung function, and smoking history (pack-years, duration of smoking abstinence) were evaluated during their first visit. At another time, the exhaled carbon monoxide level and nasal MCC were assessed in a laboratory setting. Subjects were followed for $1 \mathrm{y}$, and exacerbations were recorded.

\section{Lung Function and Exhaled CO Measurement}

Spirometry was performed according to the guidelines of the American Thoracic Society/European Respiratory Society $^{21}$ using a portable spirometer (Spirobank-MIR 3.6, Medical International Research, Rome, Italy). Reference values specific for the Brazilian population were used. ${ }^{22}$

Exhaled CO levels were used as a biochemical marker for abstinence from smoking, and were correlated with self-reported smoking status. ${ }^{23}$ Exhaled $\mathrm{CO}$ was measured using a $\mathrm{CO}$ analyzer (Micro CO Meter, Cardinal Health, Basingstoke, United Kingdom). ${ }^{24}$ Subjects were instructed to perform a deep inspiration to total lung capacity, hold their breath for $20 \mathrm{~s}$, and then exhale slowly through a mouthpiece. Two successive recordings were performed, and the highest value was used. The exhaled CO levels provide an acceptable degree of discrimination between smokers and nonsmokers and are considerably cheaper and simpler to obtain than the collection and testing of body fluids. ${ }^{25}$ 


\section{Mucociliary Clearance in COPD After Smoking Cessation}

\section{Saccharin Transit Time Test}

The saccharin transit time (STT) test is a technique for measuring nasal MCC and has been widely reported in previous studies ${ }^{26}$ as being a simple, noninvasive, valid, and reproducible method to determine the MCC. ${ }^{27-32}$ Furthermore, the nasal cavity has respiratory epithelium similar to the rest of the respiratory tract ${ }^{33}$ and the literature has established that nasal mucociliary transport has a good correlation with tracheobronchial transport, ${ }^{30,34}$ which obviates the need for more invasive procedures..$^{35}$

Subjects were seated and positioned with 10 degrees of neck extension. Granulated sodium saccharin $(250 \mu \mathrm{g})$ was placed, under visual control, $2 \mathrm{~cm}$ inside the right nostril. The time from particle placement until the first perception of a sweet taste in the mouth was recorded in minutes as measured by a digital chronometer (Kenko1046, Kenko International, Hong Kong, China). Individuals were instructed to maintain their initial position and were not allowed to breathe deeply, talk, cough, sneeze or sniff. If the sensation did not occur within $60 \mathrm{~min}$, the test was stopped and the subject's ability to perceive the taste of saccharin was verified by placing it on the tongue. If the subject was able to taste the saccharin directly, the test procedures were repeated on another occasion.

Each subject was instructed to not smoke; to not use pharmacologic agents such as anesthetics, analgesics, antiepileptics, tranquilizers, or antidepressants; and to avoid the use of alcohol and caffeine-based substances for at least $12 \mathrm{~h}$ before the test.

\section{Exacerbation History}

Exacerbations were defined as more than one of a complex of respiratory symptoms (increase or new onset): cough, sputum, sputum purulence, wheezing, or dyspnea lasting $3 \mathrm{~d}$ or more and requiring treatment with an antibiotic or a systemic corticosteroid. ${ }^{36}$ A history of exacerbations was obtained from the subject's self-report of his/her condition in the last year. The possible answers were: "not at all, once, 2-4 times, and 5 or more." In the proposed classification scheme, any exacerbation is worse than no exacerbations and more exacerbations are worse than fewer exacerbations. ${ }^{37}$

\section{Statistical Analyses}

Statistical analysis was performed using GraphPad Prism 3.0 (GraphPad, San Diego, California). The normality of data distribution was verified with the Shapiro-Wilk test. Comparisons of sample characteristics, spirometry data, smoking history, exhaled CO, and STT test values among the 4 groups were performed using one-way analysis of variance followed by the Tukey honest significant differ- ence test (FVC\% and $\left.\mathrm{FEV}_{1} \%\right)$ or Kruskal-Wallis test followed by Dunn test (age, BMI, FEV $1 / F V C$, pack-years, exhaled CO, and STT) depending on the normality of data. The Goodman test was used to compare the frequency of exacerbations among subjects with COPD, and correlation analyses were performed using Spearman's test. Differences were considered significant at $P<.05$.

\section{Results}

\section{Sample Characteristics}

Ninety-three subjects were included, consisting of exsmokers with COPD (moderate $n=10$ and severe $n=13$ ), smokers with COPD (moderate $n=10$ and severe $n=7$ ), current smokers with normal lung function $(n=27)$, and nonsmokers with normal lung function $(n=26)$. There was no difference in STT between subjects with moderate and severe COPD, so these subjects were allocated to the same group: ex-smokers with COPD (moderate COPD $\mathrm{STT}=10.6 \pm 3.6$, and severe COPD STT $=10.2 \pm 4.2$, $P=.80$ ) and smokers with COPD (moderate COPD $\mathrm{STT}=22.4 \pm 11.3$, and severe COPD STT $=18.4 \pm 8.8$, $P=.74)$. Sample characteristics, spirometric values, smoking history, and exhaled $\mathrm{CO}$ data for all groups are presented in Table 1. All groups were matched regarding age. Spirometric values were lower in both groups with COPD compared with current smokers and nonsmokers; in this last group, the $\mathrm{FEV}_{1}$ (\% predicted) was significantly higher than in smokers. Exhaled CO levels were higher in smokers with COPD and current smokers compared with the other groups.

\section{Saccharin Transit Time Data}

The STT of smokers with COPD (16.5 [11-28] min, median [interquartile range $25-75 \%$ ]), and current smokers (15.9 [10-27] min) was longer compared with exsmokers with COPD (10.2 [6-12] min) and nonsmokers (8 $[6-16] \min )(P<.001)$. There was no difference in STT values between smokers with COPD and current smokers, and these values in ex-smokers with COPD were similar to those for the control group (Fig. 1).

\section{Exacerbation History}

Table 2 demonstrates the frequency of exacerbations in subjects with COPD, in the last year. The proportion of subjects who had 5 or more episodes of COPD exacerbations was higher in smokers $(24 \%)$ compared with exsmokers with COPD $(7 \%)(P<.05)$. 


\section{Mucociliary Clearance in COPD After Smoking Cessation}

Table 1. Characteristics of Subjects in the Four Groups Evaluated

\begin{tabular}{|c|c|c|c|c|}
\hline Characteristics & $\begin{array}{l}\text { Ex-smokers } \\
\text { With COPD }\end{array}$ & $\begin{array}{c}\text { Smokers } \\
\text { With COPD }\end{array}$ & $\begin{array}{l}\text { Current Smokers With } \\
\text { Normal Lung Function }\end{array}$ & $\begin{array}{l}\text { Nonsmokers With } \\
\text { Normal Lung Function }\end{array}$ \\
\hline$n$ & 23 & 17 & 27 & 26 \\
\hline Male/Female & $13 / 10$ & $6 / 11$ & $17 / 10$ & $7 / 19$ \\
\hline \multicolumn{5}{|l|}{ Demographic } \\
\hline Age (y) & $62.4 \pm 8.0$ & $58.2 \pm 8.0$ & $61.5 \pm 6.4$ & $60.8 \pm 11.3$ \\
\hline BMI $\left(\mathrm{kg} / \mathrm{m}^{2}\right)$ & $25.9 \pm 3.7$ & $24.4 \pm 3.3$ & $25.3 \pm 2.9$ & $26.1 \pm 4.5$ \\
\hline \multicolumn{5}{|l|}{ Spirometric values } \\
\hline $\mathrm{FEV}_{1} / \mathrm{FVC}$ & $0.49 \pm 0.08^{* \dagger}$ & $0.66 \pm 0.16^{* \dagger}$ & $0.76 \pm 0.05$ & $0.84 \pm 0.09$ \\
\hline $\mathrm{FEV}_{1}(\%$ predicted $)$ & $46.8 \pm 12.6^{* \dagger}$ & $48.7 \pm 16.8^{* \dagger}$ & $90.7 \pm 7.4$ & $103.2 \pm 11.5^{*}$ \\
\hline FVC $(\%$ predicted $)$ & $76.8 \pm 18.5^{* \dagger}$ & $71.7 \pm 13.0^{* \dagger}$ & $96.3 \pm 13.9$ & $102.2 \pm 13.3$ \\
\hline \multicolumn{5}{|l|}{ Tobacco smoking behavior } \\
\hline Pack-years index & $38.8 \pm 27.6$ & $31.5 \pm 24.8$ & $39.9 \pm 21.4$ & NA \\
\hline Duration of smoking abstinence (y) & $10.1 \pm 9.9$ & NA & NA & NA \\
\hline Exhaled CO (ppm) & $3.2 \pm 1.8^{*}$ & $9.9 \pm 6.8 \dagger+$ & $8.2 \pm 4.1$ & $2.1 \pm 1.9^{*}$ \\
\hline \multicolumn{5}{|c|}{ 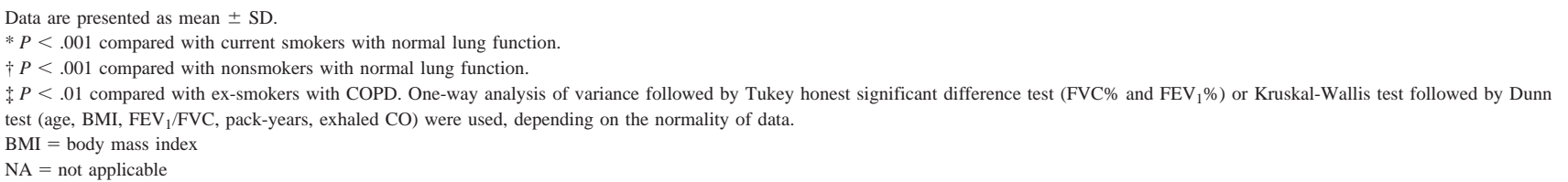 } \\
\hline
\end{tabular}

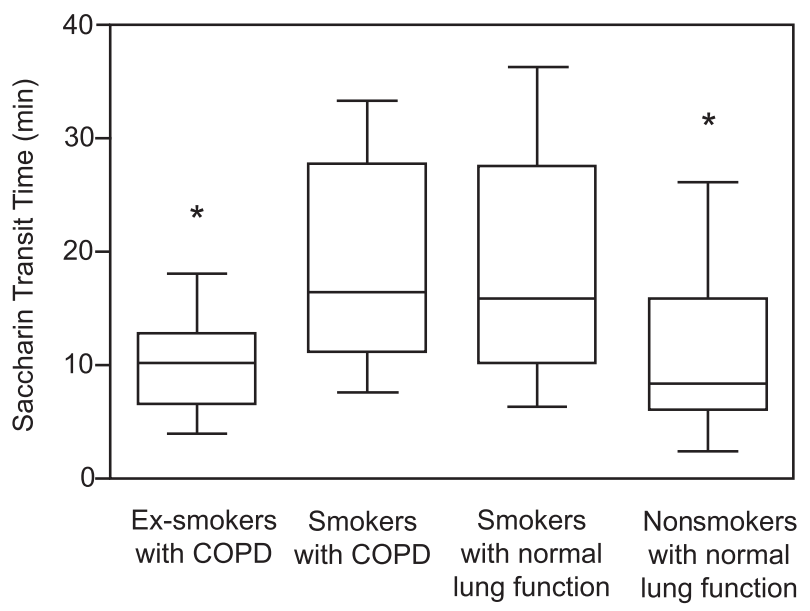

Fig. 1. Values for saccharin transit time (STT) test compared with 4 groups evaluated. Box and whisker plots show medians, interquartile range (25-75\%), and range. One-way analysis of variance followed by Tukey honest significant difference test were used. ${ }^{*} P<.0001$ compared with smokers with COPD and current smokers with normal lung function.

\section{Correlation Analysis Between STT and Frequency of Exacerbation}

There was a weak positive correlation between STT and frequency of exacerbations in both groups, smokers with COPD ( $\mathrm{r}=0.23, P=.37)$ and ex-smokers with COPD ( $\mathrm{r}=0.41, P=.14)$, with no statistical difference. The Spearman test was used.
Table 2. Frequency of Exacerbations Among COPD Groups in the Last Year

\begin{tabular}{lcc}
\hline \hline Exacerbations & $\begin{array}{c}\text { Ex-smokers } \\
\text { With COPD } \\
(\%)\end{array}$ & $\begin{array}{c}\text { Smokers } \\
\text { With COPD } \\
(\%)\end{array}$ \\
\hline $1(0 / \mathrm{y})$ & 56 & 41 \\
$2(1 / \mathrm{y})$ & 15 & 6 \\
$3(2-4 / \mathrm{y})$ & 22 & 29 \\
$4(\geq 5 / \mathrm{y})$ & $7 *$ & 24
\end{tabular}

$* P<.05$ compared with smokers with COPD. Goodman test was used to compare frequency of exacerbations between groups.

\section{Discussion}

This study showed better nasal MCC in ex-smokers with COPD and lower frequency of exacerbations compared with those who continued to smoke.

A better MCC in ex-smokers with COPD, assessed by STT, is strongly related to smoking cessation, just as has been observed in previous studies, in which smokers with normal lung function presented an improvement in this mechanism $15 \mathrm{~d}$ after quitting. ${ }^{14}$ Our results corroborate a previous study, ${ }^{38}$ in which smokers with COPD also showed worse nasal MCC than ex-smokers with COPD, but these findings presented rhinosinusitis as a tobacco-related respiratory comorbidity.

In contrast, Koblizek et al ${ }^{39}$ reported nasal MCC impairment in ex-smokers with COPD compared with healthy 


\section{Mucociliary Clearance in COPD After Smoking Cessation}

individuals who never smoked. This may due to the short period of abstinence in these subjects (from 6 months) which may have been insufficient to promote improvement in this mechanism. Thus, it would be interesting for further research to monitor a longer period after smoking cessation to ascertain the actual moment of MCC changes, in addition to investigating MCC reversibility in COPD.

In our study, the severity of COPD did not influence the MCC, unlike a previous study, ${ }^{40}$ which found a higher degree of airway inflammation in smokers with COPD with more severe obstruction. Smokers with COPD and current smokers with normal lung function showed similar nasal MCC. Vachier et $\mathrm{al}^{41}$ reported that both smokers with and without COPD presented an increase in infiltration of CD8 T lymphocytes, which plays a significant role in the pathogenesis of airway mucosal inflammation. These results indicate that MCC impairment is associated more with chronic exposure to cigarette smoke than to the disease itself. Yaghi et $\mathrm{al}^{42}$ showed worse ciliary beat frequency in COPD compared with those without the disease; however, the groups were composed of smokers and exsmokers. Given that MCC is strongly related to smoking, the constitution of these groups may have influenced this response, since, after smoking cessation, this mechanism may reverse and probably become faster in those who have not yet developed the disease.

MCC impairment in patients with COPD leads to secretion retention, airway obstruction, and recurrent airway infections, mainly in smokers. ${ }^{43-45}$ In addition, chronic exposure to cigarette smoke also leads to chronic inflammation and progressive emphysema, which contributes to the impaired lung and immune system homeostasis that plays a role in COPD exacerbations. ${ }^{6-8}$ It is known that exacerbations still occur in patients with COPD even after smoking cessation. ${ }^{46,47}$ In the present study, no correlations were found between STT and frequency of exacerbations in COPD groups; however, ex-smokers with COPD showed a low frequency of exacerbations compared with smokers with COPD, which supports the hypothesis that frequency of exacerbations may be influenced by the maintenance of smoking.

The exhaled CO level measurement is the accepted standard method for an immediate, noninvasive and effective detection of smoking status. ${ }^{23,48,49}$ This research, concurs with the observation by Chatkin et al $^{50}$ noting elevated exhaled CO levels in current smokers with normal lung function and smokers with COPD compared with nonsmokers with normal lung function and ex-smokers with COPD. The exhaled CO levels may be useful in monitoring changes in heme oxygenase enzyme activity in vivo, which might reflect inflammation or oxidative stress level in patients with airway and systemic inflammation. ${ }^{51-55}$

The improvement in MCC with lower levels of exhaled $\mathrm{CO}$ observed in our study contributes to the understanding of lung responses after smoking cessation and highlights the importance of quitting smoking in subjects with chronic pulmonary disease. Our results highlight the importance of monitoring $\mathrm{MCC}$ changes for $1 \mathrm{y}$ after smoking cessation in patients with COPD.

A limitation of the study was the small sample size despite the statistically significant differences noted in MCC among groups. Although not statistically significant, the reduction in the number of exacerbations in ex-smokers with COPD may be related to improvement of MCC in these individuals. Therefore, it is crucial to thoroughly investigate the mechanisms related to exacerbations in exsmokers with COPD.

\section{Conclusions}

This study demonstrated that smoking cessation, even in people with COPD, leads to an improvement in mucociliary clearance within $1 \mathrm{y}$ of smoking cessation.

\section{REFERENCES}

1. Tonnesen P. Smoking cessation and COPD. Eur Respir Rev 2013; 22(127):37-43

2. Global Initiative for Chronic Obstructive Lung Disease (GOLD). Global strategy for diagnosis, management, and prevention of COPD. Revised Feb 2013. http://www.goldcopd.org/uploads/users/files/ GOLD_Report_2013Feb13.pdf. Accessed Feb 5, 2014.

3. Barnes PJ, Shapiro SD, Pauwels RA. Chronic obstructive pulmonary disease: molecular and cellular mechanisms. Eur Respir J 2003; 22(4):672-688.

4. Stannard W, O'Callaghan C. Ciliary function and the role of cilia in clearance. J Aerosol Med 2006;19(1):110-115.

5. Ferri RG, Guilherme AZ, Guilherme A, Gregório IC. Análise do clearance mucociliar nasal e dos efeitos adversos do uso de CPAP nasal em pacientes com sahos. Rev Bras Otorrinolaringol 2004;70(2): $150-155$.

6. Elliott MK, Sisson JH, Wyatt TA. Effects of cigarette smoke and alcohol on ciliated tracheal epithelium and inflammatory cell recruitment. Am J Respir Cell Mol Biol 2007;36(4):452-459.

7. Vander Top EA, Wyatt TA, Gentry-Nielsen MJ. Smoke exposure exacerbates an ethanol-induced defect in mucociliary clearance of Streptococcus pneumonia. Alcohol Clin Exp Res 2005;29(5):882887

8. Cohen NA, Zhang S, Sharp DB, Tamashiro E, Chen B, Sorscher EJ, Woodworth BA. Cigarette smoke condensate inhibits transepithelial chloride transport and ciliary beat frequency. Laryngoscope 2009; 119(11):2269-2274.

9. Stanley PJ, Wilson R, Greenstone MA, MacWilliam L, Cole PJ. Effect of cigarette smoking on nasal mucociliary clearance and ciliary beat frequency. Thorax 1986;41(7):519-523.

10. Gunen H, Hacievliyagil SS, Kosar F, Mutlu LC, Gulbas G, Pehlivan $\mathrm{E}$, et al. Factors affecting survival of hospitalised patients with COPD. Eur Respir J 2005;26(2):234-241.

11. Soler-Cataluña JJ, Martínez-García MA, Román Sánchez P, Salcedo E, Navarro M, Ochando R. Severe acute exacerbations and mortality in patients with chronic obstructive pulmonary disease. Thorax 2005; 60(11):925-931. 


\section{Mucociliary Clearance in COPD After Smoking Cessation}

12. Barberà JA, Roca J, Ferrer A, Félez MA, Díaz O, Roger N, Rodriguez-Roisin R. Mechanisms of worsening gas exchange during acute exacerbations of chronic obstructive pulmonary disease. Eur Respir J 1997;10(6):1285-1291.

13. Proença M, Fagundes Xavier R, Ramos D, Cavalheri V, Pitta F, Cipulo Ramos EM. Immediate and short term effects of smoking on nasal mucociliary clearance in smokers. Rev Port Pneumol 2011; 17(4):172-176.

14. Ramos EM, De Toledo AC, Xavier RF, Fosco LC, Vieira RP, Ramos D, Jardim JR. Reversibility of impaired nasal mucociliary clearance in smokers following a smoking cessation programme. Respirology 2011;16(5):849-855.

15. Hasani A, Toms N, Agnew JE, Sarno M, Harrison AJ, Dilworth P. The effect of inhaled tiotropium bromide on lung mucociliary clearance in patients with COPD. Chest 2004;125(5):1726-1734.

16. Bhowmik A, Chahal K, Austin G, Chakravorty I. Improving mucociliary clearance in chronic obstructive pulmonary disease. Respir Med 2009;103(4):496-502.

17. Piatti G, Ambrosetti U, Santus P, Allegra L. Effects of salmeterol on cilia and mucus in COPD and pneumonia patients. Pharmacol Res 2005;51(2):165-168.

18. Anthonisen NR, Connett JE, Kiley JP, Altose MD, Bailey WC, Buist AS, et al. Effects of smoking intervention and the use of an inhaled anticholinergic bronchodilator on the rate of decline of FEV1: the Lung Health Study. JAMA 1994;272(19):1497-1505.

19. Gratziou C. Respiratory, cardiovascular and other physiological consequences of smoking cessation. Curr Med Res Opin 2009;25(2): 535-545.

20. Scanlon PD, Connett JE, Waller LA, Altose MD, Bailey WC, Buist AS. Smoking cessation and lung function in mild-to-moderate chronic obstructive pulmonary disease: the Lung Health Study. Am J Respir Crit Care Med 2000;161(2 Pt 1):381-390.

21. Miller MR, Hankinson J, Brusasco V, Burgos F, Casaburi R, Coates A, et al. Standardization of spirometry. Eur Respir J 2005;26(2):319-338.

22. Duarte AA, Pereira CA, Rodrigues SC. Validation of new Brazilian predicted values for forced spirometry in Caucasians and comparison with predicted values obtained using other reference equations. J Bras Pneumol 2007;33(5):527-535.

23. Middleton ET, Morice AH. Breath carbon monoxide as an indication of smoking habit. Chest 2000;117(3):758-763.

24. Jarvis MJ, Belcher M, Vesey C, Hutchison DC. Low cost carbon monoxide monitors in smoking assessment. Thorax 1986;41(11): 886-887.

25. Moolchan ET, Zimmerman D, Sehnert SS, Zimmerman D, Huestis MA, Epstein DH. Recent marijuana blunt smoking impacts carbon monoxide as a measure of adolescent tobacco abstinence. Subst Use Misuse 2005;40(2):231-240.

26. Salah B, Dinh Xuan AT, Fouilladieu JL, Lockhart A, Regnard J. Nasal mucociliary transport in healthy subjects is slower when breathing dry air. Eur Respir J 1988;1(9):852-855.

27. Stanley P, MacWilliam L, Greenstone M, Mackay I, Cole P. Efficacy of saccharin test for screening to detect abnormal mucociliary clearance. Chest 1984;78(1):62-65.

28. Capellier G, Zhang Z, Maheu MF, Pointet H, Racadot E, Kantelip B, et al. Nasal mucosa inflammation induced by oxygen administration in humans. Acta Anaesth Scand 1997;41(8):1011-1016.

29. Lioté H, Zahm JM, Pierrot D, Puchelle E. Role of mucus and cilia in nasal mucociliary clearance in healthy subjects. Am Rev Respir Dis 1989;140(1):132-136.

30. Plaza Valía P, Carrión Valero F, Marín Pardo J, Bautista Rentero D, González Monte C. Saccharin test for the study of mucociliary clearance: reference values for a Spanish population. Arch Bronconeumol 2008;44(10):540-545.
31. Corbo GM, Foresi A, Bonfitto P, Mugnano A, Agabiti N, Cole PJ. Measurement of nasal mucociliary clearance. Arch Dis Child 1989; 64(4):546-550.

32. Sisson JH, Yonkers AJ, Waldman RH. Effects of guaifenesin on nasal mucociliary clearance and ciliary beat frequency in healthy volunteers. Chest 1995;107(3):747-751.

33. Persson CG, Svensson C, Greiff L, Anderson M, Wollmer P, Alkner $\mathrm{U}$, Erjefält I. The use of the nose to study the inflammatory response of the respiratory tract. Thorax 1992;47(12):993-1000.

34. Andersen I, Camner P, Jensen PL, Philipson K, Proctor DF. A comparison of nasal and tracheobronchial clearance. Arch Environ Health 1974;29(5):290-293.

35. Nakagawa NK, Franchini ML, Driusso P, de Oliveira LR, Saldiva $\mathrm{PH}$, Lorenzi-Filho G. Mucociliary clearance is impaired in acutely ill patients. Chest 2005;128(4):2772-2777.

36. Halpin DM, Decramer M, Celli B, Kesten S, Liu D, Tashkin DP. Exacerbation frequency and course of COPD. Int J Chron Obstruct Pulmon Dis 2012;7:653-661.

37. Mannino DM, Diaz-Guzman E, Pospisil J. A new approach to classification of disease severity and progression of COPD. Chest 2013; 144(4):1179-1185.

38. Piotrowska VM, Piotrowski WJ, Kurmanowska Z, Marczak J, Górski P, Antczak A. Rhinosinusitis in COPD: symptoms, mucosal changes, nasal lavage cells and eicosanoids. Int J Chron Obstruct Pulmon Dis 2010;5:107-117.

39. Koblizek V, Tomsova M, Cermakova E, Papousek P, Pracharova S, Mandalia RA, et al. Impairment of nasal mucociliary clearance in former smokers with stable chronic obstructive pulmonary disease relates to the presence of a chronic bronchitis phenotype. Rhinology 2011;49(4):397-406.

40. Turato G, Zuin R, Miniati M, Baraldo S, Rea F, Beghé B, et al. Airway inflammation in severe chronic obstructive pulmonary disease: relationship with lung function and radiologic emphysema. Am J Respir Crit Care Med 2002;166(1):105-110.

41. Vachier I, Vignola AM, Chiappara G, Bruno A, Meziane H, Godard $\mathrm{P}$, et al. Inflammatory features of nasal mucosa in smokers with and without COPD. Thorax 2004;59(4):303-307.

42. Yaghi A, Zaman A, Cox G, Dolovich MB. Ciliary beating is depressed in nasal cilia from chronic obstructive pulmonary disease subjects. Respir Med 2012;106(8):1139-1147.

43. Almirall J, González CA, Balanzó X, Bolíbar I. Proportion of community acquired pneumonia cases attributable to tobacco smoking. Chest 1999;116(2):375-379.

44. Ozlü T, Cay M, Akbulut A, Yekeler H, Naziroglu M, Aksakal M. The facilitating effect of cigarette smoke on the colonization of instilled bacteria into the tracheal lumen in rats and the improving influence of supplementary vitamin $\mathrm{E}$ on this process. Respirology 1999;4(3):245-248.

45. Voynow JA, Rubin BK. Mucins, mucus, and sputum. Chest 2009; 135(2):505-512.

46. Cosio MG, Saetta M, Agusti A. Immunologic aspects of chronic obstructive pulmonary disease. N Engl J Med 2009;360(23):2445-2454.

47. Maestrelli P, El Messlemani AH, De Fina O, Nowicki Y, Saetta M, Mapp C, Fabbri LM. Increased expression of heme oxygenase (HO)-1 in alveolar spaces and HO-2 in alveolar walls of smokers. Am J Respir Crit Care Med 2001;164(8):1508-1513.

48. Kapusta ND, Pietschnig J, Plener PL, Blüml V, Lesch OM, Walter $\mathrm{H}$. Does breath carbon monoxide measure nicotine dependence? J Addict Dis 2010;29(4):493-499.

49. Stookey GK, Katz BP, Olson BL, Drook CA, Cohen SJ. Evaluation of biochemical validation measures in determination of smoking cessation. J Dent Res 1987;66(10):1597-1601. 


\section{Mucociliary Clearance in COPD After Smoking Cessation}

50. Chatkin G, Chatkin JM, Aued G, Petersen GO, Jeremias ET, Thiesen FV. Evaluation of the exhaled carbon monoxide levels in smokers with COPD. J Bras Pneumol 2010;36(3):332-338.

51. Scharte M, von Ostrowski TA, Daudel F, Freise H, Van Aken H, Bone HG. Endogenous carbon monoxide production correlates weakly with severity of acute illness. Eur J Anaesthesiol 2006;23(2): 117-122.

52. Zegdi R, Perrin D, Burdin M, Boiteau R, Tenaillon A. Increased endogenous carbon monoxide production in severe sepsis. Intensive Care Med 2002;28(6):793-796.

53. Morimatsu H, Takahashi T, Matsusaki T, Hayashi M, Matsumi J,
Shimizu $\mathrm{H}$, et al. An increase in exhaled $\mathrm{CO}$ concentration in systemic inflammation/sepsis. J Breath Res 2010;4(4):047103. doi: 10.1088/1752-7155/4/4/047103.

54. Antuni JD, Kharitonov SA, Hughes D, Hodson ME, Barnes PJ. Increase in exhaled carbon monoxide during exacerbations of cystic fibrosis. Thorax 2000;55(2):138-142.

55. Horváth I, Donnelly LE, Kiss A, Paredi P, Kharitonov SA, Barnes PJ. Raised levels of exhaled carbon monoxide are associated with an increased expression of heme oxygenase- 1 in airway macrophages in asthma: a new marker of oxidative stress. Thorax 1998;53(8):668672. 